\title{
FAKTOR-FAKTOR YANG MEMPENGARUHI KETERLAMBATAN PENYELESAIAN STUDI MAHASISWA JURUSAN PENDIDIKAN TEKNIK MESIN FPTK UPI
}

\author{
Ahmad Winardi ${ }^{1}$, Uli Karo Karo ${ }^{2}$, Maman Kusman ${ }^{3}$ \\ Departemen Pendidikan Teknik Mesin, FPTK \\ Universitas Pendidikan Indonesia \\ Jl. Dr. setiabudhi No. 207 Bandung 40154 \\ ahmad.winardi@ymail.com
}

\begin{abstract}
ABSTRAK
Penelitian ini bertujuan untuk mengetahui gambaran nyata mengenai faktor-faktor yang mempengaruhi keterlambatan penyelesaian studi mahasiswa jurusan pendidikan teknik mesin. Ada dua faktor yaitu faktor internal (faktor yang berasal dari dalam diri) dan faktor eksternal (faktor yang berasal dari luar). Faktor internal terdiri dari kecerdasan, motivasi, minat, bakat, kelelahan dan kesehatan. Faktor eksternal terdiri dari fasilitas belajar, lingkungan kampus, teman bergaul, lingkungan keluarga dan lingkungan tempat tinggal. Penelitian ini menggunakan metode penelitian deskriptif. Sampel pada penelitian ini adalah 21 mahasiswa jurusan pendidikan teknik mesin angkatan 2007. Instrumen penelitian yang digunakan yaitu angket. Hasil penelitian menunjukkan bahwa faktor internal yang menghambat penyelesaian studi, yaitu: kecerdasan, motivasi, minat dan kelelahan. Faktor eksternal yang menghambat penyelesaian studi yaitu: lingkungan kampus, waktu studi, bimbingan akademik, teman dan tempat tinggal.
\end{abstract}

Kata kunci: internal, eksternal, kelulusan, keterlambatan

\section{PENDAHULUAN}

Pendidikan adalah usaha sadar dan terencana untuk mewujudkan suasana belajar dan proses pembelajaran agar peserta didik secara aktif mengembangkan potensi dirinya untuk memiliki kekuatan spiritual keagamaan, pengendalian diri, kepribadian, kecerdasan, akhlak mulia dan serta keterampilan yang diperlukan dirinya dan masyarakat, karena itu tujuan pendidikan mempunyai dua fungsi yaitu, memberikan arahkepada segenap kegiatan pendidikan dan merupakan sesuatu yang ingin dicapai oleh segenap kegiatan pendidikan. Komponen pendidikan terdiri dari tujuan pendidikan, peserta didik, pendidik, interaksi edukatif pendidik dan anakdidik, isi pendidikan dan lingkungan pendidikan. Sebagai suatu komponen pendidikan, tujuan pendidikan menduduki posisi penting diantara komponenkomponen penting lainnya. Dapat dikatakan bahwa segenap komponen dari seluruh kegiatan pendidikan dilakukan semata-mata terarah kepada atau ditujukan untuk pencapain tujuan tersebut (Dimyanti dan Mudiono. 2006). Disini terlihat bahwa tujuan pendidikan itu bersifat normatif, yaitu mengandung unsur norma yang bersifat memaksa, tetapi tidak

\footnotetext{
${ }^{1}$ Mahasiswa Departemen Pendidikan Teknik Mesin FPTK UPI

${ }^{2}$ Dosen Departemen Pendidikan Teknik Mesin FPTK UPI

${ }^{3}$ Dosen Departemen Pendidikan Teknik Mesin FPTK UPI
} 
bertentangan dengan hakekat perkembangan peserta didik serta dapat diterima oleh masyarakat sebagai nilai hidup yang baik.

Proses pendidikan mempunyai batas waktu yang telah ditentukan oleh lembaga pendidikan tersebut, sesuai dengan tingkatan atau jenjang pendidikan, untuk menempuh suatu jenjang pendidikan siswa harus mengikuti peraturan-peraturan yang telah berlaku diinstansi tersebut, jika melebih batas waktu maka peserta didik tersebut dinyatakan gagal dalam melaksanakan proses pendidikan. Batas waktu studi ialah waktu maksimal seorang mahasiswa untuk menyelesaikan suatu program studi. Lamanya studi yang ditempuh sudah diatur atau ditentukan oleh lembaga perguruan tinggi. Adapun aturan berdasarkan Pedoman Akademik UPI, tentang lamanya studi yang ditempuh ialah sebagai berikut:

1. Lama studi setiap jenjang:

a. Lama studi untuk DIII antara 3 sampai dengan 5 tahun

b. Lama studi untuk S1 antara 4 sampai dengan 7 tahun

2. Mahasiswa yang telah melebihi batas maksimal masa studinya dinyatakan Drop Out (DO), yang surat keputusanya diterbitkan oleh Rektor atas usul Dekan Fakultas.

3. Mahasiswa yang berhenti atau tidak mendaftarkan diri selama satu semester atau lebih tanpa izin dinyatakan mengundurkan diri.

4. Lama waktu berhenti semester dengan izin resmi tidak diperhitungkan untuk penentuan batas waktu studi mahasiswa yang bersangkutan.

Tabel 1. Data Mahasiswa Angkatan 2007

\begin{tabular}{clccc}
\hline Angkatan & \multicolumn{1}{c}{ Prodi } & Lulus & Belum Lulus & Jumlah \\
\hline \multirow{3}{*}{2007} & Produksi dan Perancangan (PP) & 18 & 10 & 28 \\
& Otomotif & 25 & 6 & 31 \\
& $\begin{array}{l}\text { Refrigerasi dan Tata Udara } \\
\text { (RTU) }\end{array}$ & 15 & 5 & 20
\end{tabular}

Jumlah Total

58

21

79

Sumber: Fakultas Pendidikan Teknologi dan Kejuruan 2014

Hasil belajar yang dicapai siswa dipengaruhi oleh dua faktor utama yakni faktor dalam diri siswa dan faktor yang datang dari luar diri siswa atau faktor lingkungan (Slameto, 2010). Faktor-faktor penghambat yang dijelaskan di atas, apabila tidak segera ditanggulangi, maka dikhawatirkan akan mengganggu sistem pendidikan di Fakultas Pendidikan Teknologi dan Kejuruan khususnya pada jurusan pendidikan teknik mesin. 
Apabila hal ini terjadi pada mahasiswa, maka dikhawatirkan akan menghambat masa studinya dan terjadi DO.

Adapun akibat lain dari keterlambatan penyelesaian studi bagi mahasiswa ialah beban uang pembiayaan pelaksanaan perkuliahan bertambah dan waktu penyelesaian studi. Tujuan dari penelitian ini adalah untuk mengetahui faktor internal dan faktor eksternal apa saja yang menjadi penghambat keterlambatan penyelesaian studi.

\section{METODE PENELITIAN}

Metode penelitian yang digunakan dalam penelitian ini menggunakan metode penelitian deskriftif. Penelitian deskriptif lebih berfungsi untuk pemecahan praktis dari pada pengembangan ilmu pengetahuan. Peneliti berusaha memotret peristiwa dan kejadian yang menjadi pusat perhatiannya, kemudian menggambarkan atau melukiskannya sebagaimana adanya. Pemanfaatan temuan penelitian ini berlaku pada saat itu pula yang belum tentu relevan pada waktu yang akan datang.

Metode penelitian deskriptif pada penelitian ini yaitu dengan menggambarkan atau memaparkan faktor penghambat penyelesaian studi mahasiswa. Teknik pengumpulan data yang digunakan adalah angket dengan jumlah responden 21 mahasiswa angkatan 2007.

\section{HASIL PENELITIAN}

Data yang akan disajikan dari hasil angket penelitian ini adalah untuk memberikan gambaran tentang faktor internal dan faktor eksternal apa saja yang menjadi penghambat keterlambatan penyelesaian studi mahasiswa pendidikan teknik mesin angkatan 2007. Dari setiap pertanyaan atau pernyataan pada angket diberikan skor antara 1-5. Selanjutnya data hasil penelitian dengan skala 1-5 disebut sebagai data mentah, yang selanjutnya data mentah ini akan diolah menjadi skala persentase sehingga dapat diketahui dan disimpulkan mengenai faktor internal dan faktor eksternal yang menjadi penghambat penyelesaian studi mahasiswa pendidikan teknik mesin angkatan 2007.

Aspek yang diteliti dan dinilai pada penelitian ini meliputi faktor internal dan faktor eksternal. Adapun data hasil penelitian (Tabel 2) yang telah diperoleh yaitu faktor internal yang terdiri dari: faktor kecerdasaan, motivasi, minat, bakat dan kelelahan. Faktor eksternal yang terdiri dari: fasilitas belajar, lingkungan kampus, teman bergaul, lingkungan keluarga dan lingkungan tempat tinggal. 
Tabel 2. Hasil Penelitian

\begin{tabular}{cclccc}
\hline No & Aspek & \multicolumn{1}{c}{ Indikator } & No Item & Nilai & $\begin{array}{c}\text { Rata-rata } \\
(\%)\end{array}$ \\
\hline 1 & Internal & Kecerdasan & 1 & 74,29 & 64,13 \\
& & Motivasi & 2 & 78,10 & \\
& Minat & 3 & 56,19 & \\
& Bakat & 4 & 61,90 & \\
& Kelelahan & 5,6 & 65,71 & \\
& \multirow{5}{*}{ Eksternal } & 7 & 48,57 & \\
& Kesehatan & $8,9,10,11$ & 72,86 & 70,76 \\
& Fasilitas Belajar & $12,13,14$ & 67,62 & \\
& Lingkungan Kampus & $15,16,17$ & 68,57 & \\
& Teman Bergaul & 18 & 86,67 & \\
& Lingkungan Keluarga & 19,20 & 58,10 & \\
& Lingkungan Tempat & & & \\
& Tinggal & & & \\
\hline
\end{tabular}

Hasil penelitian yang lebih dominan menjadi penghambat penyelesaian studi mahasiswa adalah: pada faktor internal terdiri dari faktor kecerdasan, faktor motivasi, faktor minat dan faktor kelelahan. Sedangkan faktor eksternal terdiri dari faktor lingkungan kampus yang terdiri dari waktu kuliah dan bimbingan akademik yang jarang dilakukan mahasiswa, faktor teman bergaul, faktor lingkungan tempat tinggal (Suryabrata, 2010).

\section{PEMBAHASAN}

Pembahasan hasil penelitian dijelaskan berdasarkan dekripsi data yang sudah diperoleh dan diolah sebelumnya, dalam melakukan pembahasan hasil penelitian ini, peneliti menjelaskan hasil pengumpulan data yang diperoleh di lapangan berupa hasil angket. Aspek-aspek yang dibahas dalam pembahasan hasil penelitian ini, yaitu faktorfaktor yang mempengaruhi keterlambatan penyelesaian studi mahasiswa jurusan pendidikan teknik mesin FPTK UPI.

Faktor internal yaitu faktor-faktor yang berasal dari seseorang sendiri dan dapat mempengaruhi terhadap belajarnya. Faktor internal pada penelitian ini terdiri dari kecerdasan, motivasi, minat, bakat, kelelahan dan kesehatan (Mahmud, 1989).

Kecerdasan merupakan faktor psikologis yang paling penting dalam proses belajar siswa, karena itu menentukan kualitas belajar siswa. Semakin tinggi intelegensi seorang individu, semakin besar peluang individu tersebut meraih sukses dalam belajar. Sebaliknya, semakin rendah tingkat intelegensi individu, semakin sulit individu itu mencapai kesuksesan belajar. Berdasarkan hasil penelitian lebih dari setengah mahasiswa memerlukan penjelasan materi lebih dari satu kali, tentunya ini menjadi faktor dari 
keterlambatan penyelesaian studi di karenakan tidak semua mahasiswa mengerti pada saat materi disampaikan dosen bersangkutan.

Mahasiswa yang memiliki motivasi belajar akan memperhatikan pelajaran yang disampaikan, membaca materi sehingga bisa memahaminya, dan menggunakan strategistrategi belajar tertentu yang mendukung. Selain itu, mahasiswa juga memiliki keterlibatan yang intens dalam aktivitas belajar tersebut. Rasa ingin tahu yang tinggi, mencari bahanbahan yang berkaitan untuk memahami suatu topik, dan menyelesaikan tugas yang diberikan (Sadirman, 2008). Berdasarkan hasil penelitian yang dilakukan sebagian besar mahasiswa tidak memiliki motivasi. Untuk mengerti pada materi yang disampaikan, ini merupakan faktor yang menjadi keterlambatan penyelesaian studi karena rasa ingin tahu dan semangat mahasiswa untuk mengetahui dan mengerti materi tidak ada.

Minat besar pengaruhnya terhadap belajarnya seseorang, karena jika bahan pelajaran tidak sesuai dengan minat seorang, maka sesorang tersebut tidak akan belajar dengan sungguh-sungguh. Realita kehidupan tidak semua individu memiliki minat yang sama terhadap objek yang sama, apalagi pada objek berbeda. Demikian halnya dengan mahasiswa sebagai individu, tentu saja memiliki minat yang berbeda dalam belajar untuk menyelesaikan studinya. Berdasarkan hasil penelitian yang dilakukan lebih dari setengah minat mahasiswa terhadap jurusan yang dipilih tidak sesuai dengan keinginan sendiri. Ini merupakan faktor yang menjadi terjadinya keterlambatan, mahasiswa tidak memiliki minat yang cukup besar pada jurusan tersebut sehingga semangat untuk menyelesaikan materi perkuliahan tidak ada (Sudrajat, 2008).

Pada dasarnya setiap orang mempunyai bakat atau potensi untuk mencapai prestasi belajar sesuai dengan kemampuannya masing-masing. Karena itu, bakat juga diartikan sebagai kemampuan dasar individu untuk melakukan tugas tertentu tanpa tergantung upaya pendidikan dan latihan. Individu yang telah mempunyai bakat tertentu, akan lebih mudah menyerap informasi yang berhubungan dengan bakat yang dimilikinya. Misalnya, mahasiswa yang berbakat dibidang bahasa akan lebih mudah mempelajari bahasa-bahasa yang lain selain bahasanya sendiri. Hasil penelitian yang dilakukan lebih dari setengah mahasiswa mengerti sedikit-sedikit tentang mesin, dalam hal ini tidak menjadi faktor keterlambatan penyelesaian studi dikarenkan sebelum masuk di jurusan teknik mesin mahasiswa telah mengerti sedikit-sedikit tentang mesin.

Kelelahan adalah suatu perasaan yang bersifat subjektif. Kelelahan adalah aneka keadaan yang disertai penurunan efisiensi dan kebutuhan dalam bekerja. Dari hasil penelitian yang dilakukan lebih dari setengah mahasiswa merasa pusing dan ngantuk 
ketika menerima materi perkuliahan. Dalam hal ini menjadi faktor keterlambatan penyelesaian studi dikarenakan pada saat dosen menjelasakan materi, mahasiswa mengantuk dan pusing, dalam keadaan seperti itu tentunya sulit untuk dapat mengerti materi yang disampaikan.

Faktor eksternal yaitu faktor-faktor yang berasal dari lingkungan luar dan dapat mempengaruhi terhadap belajarnya. Alat pelajaran yang dimiliki erat hubungannya dengan cara dan hasil belajar mahasiswa, karena alat pelajaran yang dimiliki oleh mahasiswa akan dipakai pada waktu belajar. Hasil penelitian yang dilakukan sebagian besar mahasiswa memiliki fasilitas belajar yang cukup untuk mahasiswa mengerjakan tugas kuliah. Dalam hal ini tidak menjadi kendala keterlambatan penyelesaian studi (Subroto. \& Arianto, 2008).

Faktor lingkungan kampus yang mempengaruhi belajar pada mahasiswa ini mencakup: waktu kuliah dan bimbingan akademik. Hasil penelitian yang dilakukan yang terdiri dari waktu kuliah, bimbingan dan sarana prasaran hanya waktu kuliah yang menjadi kendala dalam keterlambatan penyelesaian studi, dikarenakan lebih dari setengah mahasiswa tidak bisa kuliah pagi.

Pengaruh-pengaruh dari teman bergaul mahasiswa lebih cepat masuk dalam jiwanya daripada yang kita duga. Hasil penelitian lebih dari setengah mahasiswa melakukan kegiatan tidak bermanfaat hingga larut malam bersama teman-temannya. Dalam hal ini tentunya menjadi kendala dalam penyelesaian studi mahasiswa.

Keluarga sebagai lembaga pendidikan yang utama dan pertama tidak dapat dipandang sebelah mata perannya dalam membangun dan mempengaruhi anak dalam belajar. Hasil penelitian hanya sebagian kecil mahasiswa yang memiliki kendala dalam keluarga dalam artian orang tua sering atau tidaknya menanyakan perkembangan perkuliahan. Lingkungan keluarga tidak menjadi faktor keterlambatan penyelesaian studi mahasiswa (Herijulianti, 2001).

Lingkungan tempat tinggal mempengaruhi sikap anak dalam belajar. Perlu kepada mahasiswa ditanamkan kebiasaan-kebiasaan yang baik, agar mendorong semangat mahasiswa untuk belajar. Hasil penelitian berdasarkan indikator ada atau tidak tempat hiburan dekat tempat tinggal mahasiswa hingga larut malam (tempat nongkrong, bermain kartu) lebih dari setengah mahasiswa mengatakan ada, ini merupakan kendala dalam penyelesaian studi mahasiswa dikarenakan mahasiswa akan terpengaruh untuk mengikuti kegiatan sekitar rumah hingga larut malam. 


\section{KESIMPULAN}

Kesimpulan penelitian ini yaitu faktor internal yang menghambat penyelesaian studi mahasiswa Jurusan Pendidikan Teknik Mesin FPTK UPI yaitu; faktor kecerdasan, faktor motivasi, faktor minat dan faktor kelelahan. Faktor eksternal yang menghambat penyelesaian studi mahasiswa Jurusan Pendidikan Teknik Mesin FPTK UPI yaitu; faktor lingkungan kampus yang terdiri dari waktu kuliah dan bimbingan akademik yang jarang dilakukan mahasiswa, faktor teman bergaul, faktor lingkungan tempat tinggal.

\section{DAFTAR PUSTAKA}

Dimyanti dan Mudiono. (2006). Belajar dan Pembelajaran. Jakarta: PT Asdi Mahasatya. Herijulianti. (2001). Lingkungan Keluarga. [Online]. Tersedia: http://www.slideshare.net

Mahmud, D. (1989). Faktor-faktor yang Mempengaruhi Prestasi Belajar Siswa. [online] tersedia di: http://www.wordpress.com.

Sadirman. (2008). Interaksi dan motivasi belajar mengajar. Jakarta: PT. Raja Grafindo Persada.

Slameto. (2010). Belajar dan Faktor-faktor yang mempengaruhinya. Jakarta: Rineka Cipta.

Subroto. \& Arianto. (2008). Fasilitas Belajar. [Online] Tersedia di: http://www.psychologymania.com

Sudrajat, A. (2008). Tujuan Bimbingan dan Konseling. [Online] Tersedia di: http://www.wordpress.com/2008/03/14.

Suryabrata, S. (2010). Psikologi Pendidikan. Jakarta: PT Raja Grafindo Persada. 